\title{
POLA PENGAMBILAN KEPUTUSAN PELAPAK DAN PENAWAR LELANG ACTION FIGURE: STUDI KASUS LAPAK LELANG INDONESIA
}

\author{
Aris Surya Putra \\ Universitas Surabaya \\ aris.sp@staff.ubaya.ac.id \\ Bonnie Soeherman \\ Universitas Surabaya \\ bonnie_s@staff.ubaya.ac.id
}

\begin{abstract}
This study seeks to examine in depth the behavior of pelapak and bidder for the Action Figure $(A F)$ auction and then try to find the pattern of decision making for the second stakeholder transaction. The method of obtaining data is carried out by in-depth interviews and participatory observation, as well as detailed documentation studies of several auctioneers and bidder bidders. This research reveals empirical data from the perspective of auctioneers and auction bidders so as to get a holistic picture of the twists and turns of AF auctions. From the study conducted on the pelapak, there were found two models of AF auctioners, namely opportunistic models and fair models. From the study conducted by the bidder, it was found 5 behavioral patterns and decision making for bidder bids, namely Fad, Conservative, Aggressor, Sniper, Binary. Each of these types has a very interesting uniqueness to look at and color the concept of the relevant business world.
\end{abstract}

Kata kunci: pengambilan keputusan; lelang; action figure

\section{PENDAHULUAN}

Kunci utama untuk memenangkan persaingan di era ini adalah kreativitas dan empati. Era konseptual ini menuntut setiap bisnis untuk tetap kreatif, inovatif, dan berempati kepada pelanggan supaya dapat bertahan hidup. Gulden (2015) mengungkap bahwa bisnis mainan kini memanfaatkan strategi pemasaran berupa transmedia storytelling (TS). Keberhasilan implementasi strategi TS tersebut dapat mendongkrak penjualan merchandise. Laporan keuangan tahun 2015 sebuah perusahaan mainan Jepang ternama, BANDAI NAMCO, mencatat penjualan dari unit bisnis 'toys and hobby' sebesar 230,9 milyar Yen. Angka sebesar $38,6 \%$ dari total penjualan tersebut diraup dari lini produk: toys, vending machine capsule toys, sundries, plastic models, cards, stationery, confectionery, foods, dan apparel.

Pernyataan dari Taro Tsuji, Direktur BANDAI NAMCO ASIA CO., LTD., menunjukkan bahwa Negara Indonesia merupakan target pasar potensial. Peneliti mengamati melalui media social Facebook, bahwa masyarakat Indonesia benar sedang dijajah action figure (AF) produksi Jepang. Peneliti mengamati besarnya nilai perputaran uang dalam bisnis AF di Indonesia dilihat dari intensitas transaksi jual-beli di Facebook setiap harinya. Sebagian besar teori akuntansi dan ekonomi berasumsi bahwa manusia makhluk rasional. Namun dalam dunia AF sangat kontradiktif dengan teori tersebut. Perilaku unik ini makin terlihat jelas pada fenomena transaksi dengan model lelang.

Perilaku peserta lelang (penawar) AF pun mulai menggoyah sebagian besar teori akuntansi dan ekonomi yang berasumsi bahwa manusia merupakan makhluk rasional dalam mengambil keputusan untuk membeli barang. Alasan penawar untuk memberanikan diri 
mengikuti dan memenangkan lelang AF sangat dipengaruhi aspek irasional seperti kecintaan terhadap karakter AF, kelangkaan AF, dan keinginan untuk aktualisasi diri. Terdapat pula perilaku pelapak yang kreatif dalam merangsang emosi penawar untuk menawar harga dengan memanfaatkan informasi-informasi AF terkait dari berbagai media. Sehingga penelitian ini dapat menggambarkan bagimana keunikan pola pengambilan keputusan pelapak maupun penawar. Keunikan ini mendorong peneliti untuk melakukan investigasi lebih dalam untuk menemukan jawaban Bagaimana model konseptual pemrosesan informasi dan pengambilan keputusan pelapak dan penawar pada lelang AF?

Penelitian kualitatif ini merupakan exploratory research untuk mengungkap pemahaman dan memberikan pengetahuan baru terhadap sesuatu permasalahan atau isu penelitian (Neuman, 2011). Kemudian penelitian ini menghasilkan wawasan dan pemahaman mengenai fenomena yang dibahas sehingga dapat memberikan kontribusi terhadap teori berkaitan. Penelitian ini didasari dengan teori-teori mengenai bisnis dan keperilakuan, dinamika paradigma akuntansi keperilakuan, pengambilan keputusan, pendalaman model sosial, model konseptual keputusan, imajinasi dan kreativitas, bias dalam proses informasi, pengetahuan dan penelitian lelang, dan siklus pendapatan dalam lelang.

\section{TELAAH TEORETIS}

Proses lelang dipercaya mulai dikembangkan pada masa Nabi Yusuf ketika pada masa mudanya ia dijual kepada Mesir melalui mekanisme lelang. Perkembangan operasi lelang menjadi daya tarik bagi dunia akademis dengan munculnya banyak penelitian tentang lelang dan perilaku manusia, baik dari sisi pelapak atau penawar. Sebagai contoh penelitian Huang et. al. (2011) yang mencoba mengangkat sisi unik lelang online dari perspektif pembeli. Penelitian ini menggunakan teori perilaku terencana (theory of planned behavior) dan menemukan bahwa pengalaman masa lalu terhadap lapak akan memengaruhi keputusan memilih lapak berikutnya sehingga pengalaman baik harus dibangun oleh pelapak. Sebuah pengalaman untuk membangun kepercayaan pada akhirnya menjadi nalai jual sebuah lapak (Chiou et al., 2009).

\section{METODE PENELITIAN}

Burrell dan Morgan (1979) memaknai bahwa manusia selalu menyatu dengan realitas (obyek) penelitian. Sehingga unsur subyektifitas dalam perolehan dalam perolehan data serta analisis kualitatif akan diutamakan dalam penelitian ini. Peneliti terlibat langsung dalam kegiatan operasional dan proses pencarian makna yang pada akhirnya melahirkan asumsiasumsi dan pemikiran baru dalam bentuk model konseptual. Mickhail (2000) mengungkapkan hal yang sama bahwa pendekatan subyektif sebenarnya justru membongkar tembok dikotomi subyek-obyek atau yang dikenal dengan pendekatan kualitatif-kuantitatif. Dikotomi tersebut telah dipandang jauh sebelumnya oleh Tinker dan Neimark (1987) bahwa perilaku dan bahasa manusia merupakan hla yang melekat dalam praktik sosial seperti akuntansi. Dunia sosial dianalogikan sebagai teks yang tidak dapat dipahami selain melalui interpretasi manusia.

Penelitian ini menggunakan triangulasi beberapa metode pengumpulan data supaya data yang diperoleh dapat diandalkan. Metode yang digunakan antara lain: observasi partisipan, wawancara, dan dokumentasi. Pengumpulan data ini akan dilakukan dalam 3 fase yaitu: (1) Persiapan, meliputi perancangan penelitian dan perolehan akses pada beberapa pelapak aktif di Facebook. Perancangan penelitian dilakukan dengan menggunakan metode observasi 
partisipan yang dilengkapi dengan wawancara terhadap pelapak maupun penawar untuk mempertajam data yang diperoleh. Peneliti juga akan menentukan beberapa skema observasi partisipan untuk pengkondisian proses lelang AF. Sedangkan perolehan ijin akses pada pelapak sudah diperoleh karena peneliti selama ini memiliki kedekatan hubungan sebagai pembeli pada pelapak. (2) Pengumpulan data, dalam konteks penelitian ini, data akan dikumpulkan melalui proses triangulasi observasi partisipan, wawancara, dan dokumentasi. Hal ini sejalan dengan pernyataan Bryman (2002) bahwa observasi partisipan tetap harus ditunjang dengan wawancara dan catatan lapangan. Triangulasi yang dimaksud adalah proses validasi silang (Wiersma, 1986), baik melalui triangulasi metode maupun triangulasi sumber untuk membangun kekuatan data. Proses triangulasi pada penelitian ini bukan bertujuan untuk mencari kebenaran, namun lebih pada upaya peningkatan pemahaman peneliti terhadap temuan. Adapun kegiatan pengumpulan data dilakukan sekitar 6 bulan sejak bulan Februari hingga Juli 2016. (3) Analisis, dilakukan bersamaan pada saat pengumpulan data dan dilanjutkan pasca pengumpulan data. Selama proses analisis, sangat dimungkinkan peneliti kembali ke lapangan untuk mengkonfirmasi kembali pernyataan yang belum jelas dan mencari bukti lanjutan (Bogdan, 1973). Analisis secara intensif dilakukan terhadap data hasil observasi, wawancara, dan dokumentasi. Kemudian data yang diperoleh akan dikelompokkan sesuai dengan topik bahasan. Setelah pengelompokan dilakukan, dilakukan pembacaan ulang dan analisis konten untuk menemukan konten pembicaraan dan temuan yang penting untuk menemukan nilai dan makna. Upaya ini dilakukan melalui proses interpretasi untuk mencapai informasi yang bernilai dari proses refleksi atau Alvensson dan Skoldberg (1994) menyebutnya dengan interpretasi pada interpretasi. Kemudian berdasarkan data dan hasil analisis tersebut, peneliti akan menggambarkan sebuah proposisi atau model konseptual pemrosesan informasi dan pengambilan keputusan pelapak dan penawar pada lelang AF. Secara menyeluruh, proses pengumpulan data dirangkum di dalam bagan 1 berikut. 


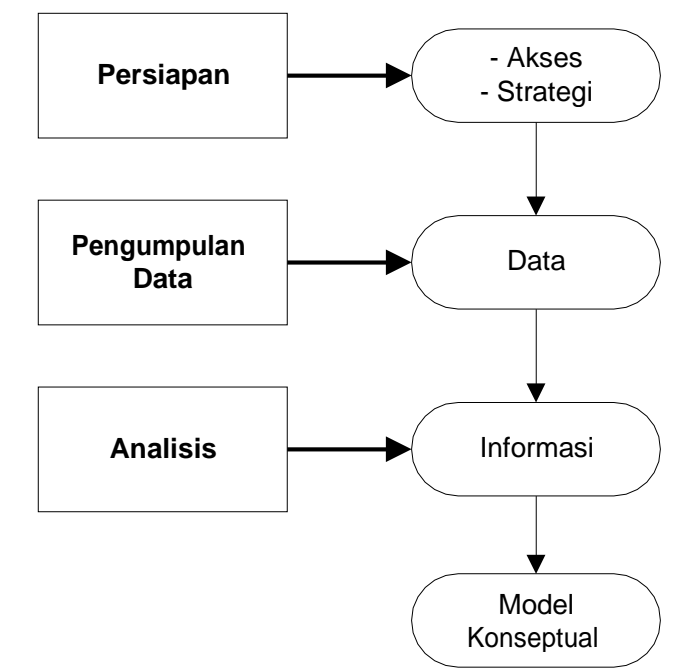

Gambar 2. Tahapan Pengumpulan Data

Sumber: olahan

Untuk menjaga validitas data, penelitian ini akan menggunakan teknik triangulasi, dimana setiap data observasi akan dibandingkan dengan data wawancara, serta studi dokumentasi dan sebaliknya. Proses wawancara juga tidak terbatas pada satu pihak pelapak, namun juga pada pihak penawar lelang untuk mendapatkan dua perspektif sekaligus sebagai dasar konfirmasi atas kebenaran data. Demikian pula dengan observasi dilakukan tidak hanya pada satu lapak lelang, namun langsung pada beberapa lapak dengan metode partisipan. Sedangkan untuk menjaga reliabilitas data, pemilihan narasumber dan obyek pengamatan akan mempertimbangkan kredibilitas dan traffic dari setiap lapak yang disasar.

Metode analisis data akan menggunakan teknik coding sederhana dan pendekatan interpretif. Teknik coding dilakukan dengan cara mengelompokkan data berdasarkan klasifikasi mini research question. Kemudian, dicari hubungan antar data dengan runtutan perpikir sesuai tujuan dan pertanyaan penelitian hingga mencapai sebuah rangkaian cerita sebagai dasar pembahasan dan jawaban pertanyaan penelitian menyeluruh. Pendekatan interpretif dilakukan dengan membandingkan antara data dengan konsep teori yang telah dan kemudian dijadikan dasar argumentasi peneliti terkait dengan pencarian jawaban atas pertanyaan penelitian.

\section{PEMBAHASAN}

\section{Komunitas Action Figure di Indonesia}

Media sosial seperti Facebook kini menjadi "tempat nongkrong" penggemar AF. Facebook menjadi diminati para pelaku dunia AF oleh karena tersedianya fitur foto, video, komentar, group, chatting, fanpage, dan search engine yang memudahkan para pelaku dunia AF. Terdapat berbagai komunitas AF di Indonesia yang menjamur di dunia maya khususnya Facebook. Berbagai komunitas didirikan dengan berbagai tujuan seperti fotografi, berbagi informasi, jual-beli, barter, dan lelang. Komunitas dalam bentuk maya ini menjadi media nyata untuk menjalin hubungan antar-kolektor.

Berbagai nama komunitas tersebut memiliki ciri-ciri dan pasar khusus. Sebagai contoh Jual Beli Mainan dan KAFI yang mewadahi stakeholder AF berbagai merek dan jenis dengan jumlah anggota hingga melebihi 15.000. Dalam hal ini komunitas Asongan Action figure \& Robot 100k kebawah memiliki jumlah anggota terbesar, hingga 25.778. Menariknya, 
komunitas ini berisikan jual beli segala mainan dengan harga maksimum 100.000. Berbeda dengan Bandai Indonesia yang hanya menampung stakeholder terkait dengan produk merk spesifik, seperti Bandai atau Lapak SCMR yang hanya menampung hal terkait dengan karakter atau intellectual property Saint Seiya. Komunitas AF di Indonesia berusaha membangun pasarnya sendiri secara unik dan mereka hidup setiap hari, tanpa kenal batas ruang dan waktu. Mereka aktif melakukan transaksi, jual-beli dan lelang dengan perputaran uang yang besar.

\section{Pelapak Lelang Action Figure di Indonesia}

Melalui bagian ini peneliti akan menunjukkan data pelapak lelang yang menjadi obyek penelitian. Berikut tabel yang menunjukkan jumlah follower, rata-rata jumlah barang yang dilelang, rata-rata omzet per-lelang, dan intensitas penyelenggaraan lelang yang disajikan pad lampiran 1. Setiap pelapak memiliki aturan main yang beragam. Dari informasi yang didapatkan, hal ini terjadi karena variasi orientasi pelapak. Ada yang memang penuh waktu bekerja sebagai pelapak dan ada yang menjadikan bisnis AF sebagai bisnis sampingan saja. Dalam satu putaran lelang saja, sebuah lapak mampu mendapatkan omset hingg angka 22 juta rupiah hanya dari 22 barang seperti yang dilakukan pelapak HAN, mengingat harga per-AF bisa mencapai 1 juta rupiah.

Untuk satu putaran lelang, ada yang berdurasi sehari semalam, 3 hari, bahkan sampai dengan 5 hari. Berbagai pilihan durasi demikian ternyata memiliki pasarnya sendiri. Makin lama durasi lelang, makin ketat pula persaingannya karena makin banyak orang yang tahu dan ikut berjuang. Untuk tipe pejuang, durasi panjang akan menjadi permainan yang menyenangkan. Meskipun pelapak memiliki aturan masing-masing, namun secara sistem transaksi, tidak ada perbedaan yang sangat signifikan diantara mereka. Setiap lapak lelang selalu memiliki ciri utama yaitu tanggal dan waktu penutupan lelang. Ketentuan tanggal dan waktu penutupan lelang selalu ada karena sifat dasar dari lelang adalah adanya batasan waktu. Waktu penutupan lelang tersebut tertuang dalam setiap peraturan yang ditetapkan oleh pelapak. Terdapat dua macam waktu penutupan yaitu waktu penutupan tetap dan waktu penutupan dengan perpanjangan waktu. Waktu penutupan tetap berarti waktu penutupan lelang ditetapkan pada suatu waktu tanpa adanya tambahan perpanjangan waktu bid. Sedangkan waktu penutupan dengan perpanjangan waktu akan memungkinkan adanya perpanjangan waktu bid setelah waktu penutupan yang telah ditetapkan. Perpanjangan waktu diterapkan oleh pelapak untuk memperoleh peluang naiknya harga bid karena adanya sniper bid menjelang berakhirnya lelang.

Setiap barang yang dilelang selalu memiliki harga bid awal yang ditetapkan oleh pelapak. Harga bid awal yang ditetapkan oleh masing-masing pelapak berbeda-beda. Pelapak yang termasuk risk avoider memiliki kecenderungan menentukan harga bid awal yang cukup tinggi. Sedangkan pelapak yang bersifat risk taker memiliki kecenderungan menentukan harga bid awal serendah-rendahnya. Keberanian menentukan harga bid awal pelapak ditentukan oleh jumlah pengikut dan pelanggan. Semakin banyak pengikut dan pelanggan yang dimiliki seorang pelapak, maka semakin berani pelapak menetapkan harga bid awal yang rendah. Hampir seluruh pelapak menetapkan harga BIN untuk setiap barang yang dilelangnya. Hal ini diadakan untuk mengakomodasi pembeli yang irasional dan tidak sabar menunggu lelang berakhir. Selain itu, harga BIN dapat menjadi peluang bagi pelapak untuk membuat barang yang dilelang segera laku. Akan tetapi, beberapa pelapak tidak menetapkan harga BIN khusus untuk barang-barang langka. Karena pelapak percaya bahwa barang langka mampu menembus harga lebih dari ekspektasi.

Setiap barang yang dilelang tentu diwakili dengan sebuah foto yang dipublikasikan di media sosial Facebook. Tidak semua pelapak memajang foto fisik barang secara langsung. 
Beberapa pelapak berkeyakinan bahwa foto yang diambil dari internet dengan angle dan kualitas foto yang baik akan dapat merangsang penawar secara visual. Namun beberapa pelapak juga ada yang tetap berusaha menggunakan foto fisik barang secara langsung. Hal ini dikarenakan pelapak berusaha ingin menunjukkan kondisi barang yang sebenarnya secara nyata. Selain foto, setiap barang yang dilelang selalu diberi deskripsi mengenai kondisi barang tersebut oleh pelapak. Deskripsi tersebut dilakukan oleh pelapak dengan tujuan untuk memberikan informasi mengenai kondisi barang yang dilelang. Beberapa pelapak menggunakan kata-kata "mungkin ada lecet yang lolos dari sepengelihatan mata saya" untuk memberikan pengertian kepada penawar akan kondisi yang diungkapkan memungkinkan berbeda sedikit dari ekspektasi. Hal tersebut dikarenakan kemungkinan adanya perbedaan standar lecet antara pelapak dan penawar.

Toleransi pelunasan setiap pelapak umumnya ditetapkan maksimal dua kali 24 jam. Hal ini diberlakukan karena pelapak tidak ingin mengalami permasalahan likuiditas. Akan tetapi beberapa pelapak memberikan kelonggaran pelunasan dengan pengajuan termin pembayaran. Meskipun penawar berhak mengajukan termin pembayaran, namun keputusan otorisasi tetap berada di tangan pelapak. Beberapa pelapak juga telah mengakomodasi pembayaran menggunakan marketplace online bagi penawar yang ingin memanfaatkan jasa rekening bersama maupun pembayaran melalui kartu kredit. Sedangkan untuk metode pengiriman barang, pelapak mayoritas menggunakan jasa ekspedisi pihak ketiga. Pelapak hanya menyediakan pilihan jasa ekspedisi yang tersedia di daerah domisili pelapak. Sedangkan untuk penawar yang sesama kota dengan pelapak, maka penawar umumnya diperbolehkan untuk datang langsung bertemu dengan pelapak untuk melunasi sekaligus mengambil barang.

\section{Perilaku dan Pola Pengambilan Keputusan Pelapak}

Bagian ini akan memberi penekanan pada tujuh poin utama perilaku pelapak AF yang akan menjadi dasar pengembangaan model konseptual pola pengambilan keputusan pelapak, yaitu: (1) Konsentrasi berbisnis. Konsentrasi atau fokus dalam berbisnis merupakan kunci eksistensi dan sustainability pelapak. Terdapat 2 tipe pelapak, mereka yang mendedikasikan waktunya secara penuh untuk bisnis AF dan mereka yang menjadikan bisnis AF sebagai sambilan. tentu saja, pelapak penuh waktu seperti HAN memiliki kesempatan lebih banyak untuk menyebarkan (share) lapaknya di berbagai komunitas terkait serta memantau pergerakan angka lelang. Berbeda dengan yang menjadikan lelang sebagai bisnis sampingan. Mereka yang menjadi pengusaha seperti HSN atau EFL masih memiliki waktu yang cukup untuk menyebarkan dan memantau lapak. Sedangkan mereka yang menjadi karyawan penuh waktu di perusahaan orang tentu tidak memiliki waktu yang cukup banyak untuk ini seperti dialami oleh AHS dan Samz. Salah satu dampak dari ketekunan ini adalah jumlah masa (friends atau followers). Mereka yang penuh waktu tentu berpeluang lebih besar mengundang orang untuk bergabung. (2) Barang lelangan. Jenis barang yang dilelang merupakan faktor utama dalam bisnis AF. Di dalam dunia perkoleksian AF, bahkan konsumen tidak pernah setia pada merk toko atau pelapak tertentu. Mereka setia pada karakter AF yang mereka cari. Dengan kata lain, siapapun pelapaknya, selama tersedia barang yang dicari dan bonafit sistemnya, konsumen akan tetap memburunya. Dari perspektif kepemilikan, terdapat barang stok pelapak dan barang titipan. Stok pelapak adalah hasil pembelian pelapak yang memang hendak dijual baik dengan cara langsung atau lelang. Sedangkan barang titipan adalah barang dari rekanan pelapak yang ingin dibantu untuk dilelang. Umumnya, barang tersebut adalah koleksi pribadi yang ingin dijual. Adapun alasan titip lelang antara lain adalah kredibilitas dan faktor kepraktisan daripada harus menggelar lapak sendiri. Dari perspektif kelangkaan, terdapat dua tipe baraang AF yaitu barang pasaran dan langka. Keduanya memiliki pasarnya 
sendiri. Untuk barang langka, biasanya lapak diramaikan oleh kolektor dan penjual lain. (3) Waktu lelang, extend atau tetap. Waktu, merupakan salah satu kendali psikologis. Batasan waktu akan memengaruhi pola pengambilan keputusan. Dari pelapak yang diamati, terdapat 2 kategori umum penetapan waktu lelang, durasi dan ekstensi. Durasi terbagi ke dalam dua pola yaitu durasi pendek yang kurang dari 2 hari dan durasi panjang lebih dari 2 hari. Di luar durasi tersebut, terdapat juga durasi yang unik seperti semalam saja. Bagi pelapak, makin lama durasi, maka peluang menarik masa akan lebih panjang khususnya untuk lapak yang belum memiliki jumlah anggota besar. Dari perspektif ekstensi waktu, ada pelapak yang menggunakan waktu penutupan tetap, misalnya pukul 24.00 WIB tanpa tambahan waktu. Sebaliknya, dengan ekstensi waktu dimana pelapak selalu menambahkan tambahan waktu penutupan melebihi yang seharusnya, misanya penutupan pukul 24.00 WIB dengan ekstensi 10 menit jika pada pukul 24.01 masih ada penawar. Dari perspektif pelapak, hal ini dilakukan untuk memainkan emosi penawar, mereka akan saling bersaing berjuang menjadi pemenang. (4) Penentuan harga pembukaan (Open Bid). OB dapat menjadi jangkar (anchoring) bagi para penawar. Makin dekat OB dengan harga pasaran atau BIN (Buy It Now), makin sedikit animo masyarakat karena pada dasarnya, penawar juga makhluk ekonomis yang mencari harga terendah. Kedekatan OB dengan harga pasar atau BIN banyak ditemui oleh pelapak yang melelang barang titipan. Hal ini dikarenakan penitip ingin mendapat harga tertinggi sehingga tidak mau memasang OB terlalu rendah. Untuk pelapak besar yang bermodal kuat dan memiliki masa yang besar, mereka lebih berani memasang OB rendah, bahkan dari 0 rupiah. Tentunya, hal ini akan sangat menarik dari perspektif penawar. Selain itu, OB 0 rupiah juga kerap dijumpai pada barang yang harganya relatif murah hingga Rp.300.000,-. Dalam hal ini, pelapak harus memahami benar sifat produk dan perilaku anggotanya. Jika tidak, ia akan terjebak dalam kondisi anchoring bias (Bazerman, 2013). Selain OB, anchoring dapat dibangun melalui penetapan BIN. (5) Penetapan BIN. Penetapan BIN memerlukan kecermatan tinggi tentang sifat dasar produk yang dilelang, ada produk pasaran dan langka. Penetapan BIN akan menjadi masalah bagi pelapak jika terlalu rendah. Pada sebuah observasi partisipan, peneliti mengamati angka BIN yang terlalu rendah untuk barang langka pada sebuah lapak dan akibatnya, belum genap 1 jam sudah ada penawar yang melakukan BIN. Sebaliknya, angka BIN yang terlalu tinggi tidak akan menjadi masalah berarti, terutama untuk barang yang benar-benar langka. Idealnya, angka BIN memang perlu mempertimbangkan harga pasaran, terutama untuk barang pasaran karena BIN yang terlalu tinggi akan mengurangi motivasi penawar untuk bergabung dan bagi mereka lebih praktis untuk membeli di lapak lain yang sudah pasti, hal ini juga sebagai bentuk terjadinya anchoring bias. (6) Pemilihan foto. Foto, merupakan salah satu faktor penguat lelang. Foto ibarat iklan, makin bagus kualitasnya, maka makin besar pula ketertarikan orang. Seperti penelitian Lo et. al.(2013) bahwa foto sangat memengaruhi keputusan penawar lelang online. Dari pengamatan yang dilakukan, terdapat dua pola pemilihan foto. Pertama, pelapak yang menggunakan foto orang lain (misalnya dari official page produsen). Sebagian besar, mereka merasa malas untuk foto produk satu persatu mengingat faktor ribet. Bagi pelapak lama yang sudah memiliki citra baik, tentunya menggunakan foto dari official page bukan lagi menjadi masalah karena unsur kepercayaan sudah terbangun. Kedua, pelapak yang selalu menggunakan foto asli barang. Mereka menyempatkan diri untuk mengambil gambar satu persatu. Tentunya, hal ini diharapkan akan meningkatkan kepercayaan calon penawar, khususnya untuk pelapak yang belum memiliki masa yang besar. (7) Peraturan pelunasan. Pelunasan adalah prosesi akhir dari siklus pendapatan. Dalam dunia transaksi online ada sedikit keunikan tentang sistem pembayaran. Biasanya pelapak memberikan 2 alternatif jalur pembayaran pemenang lelang. Pertama menggunakan transfer langsung ke nomor rekening bank pelapak. Hal ini dapat terjadi jika sudah terbangun saling percaya antara pelapak dan pemenang. Jika tidak, dapat 
menggunakan alternatif kedua, melalui rekening besarama pihak ke-tiga seperti Tokopedia. Memang sedikit lebih rumit, namun nampaknya para stakeholder AF sudah sangat menguasai prosedurnya. Setelah pengumuman pemenang, biasanya pelapak akan mem-posting barang tersebut di Tokopedia atau Bukalapak dengan catatan khusus pada caption, misalnya "Tagihan si Budi" dan jumlah nominal sesuai deal. Bagi pelapak, fasilitas ini juga sangat menguntungkan, mengingat mereka dapat memanfaatkan berbagai fasilitas marketplace seperti gratis ongkir atau cicilan $0 \%$.

\section{Model Konseptual Perilaku Pelapak Lelang AF}

Ketujuh poin temuan tersebut (ketekunan, jenis barang, foto, penentuan OB, penentuan BIN, waktu, dan pelunasan) akan dijadikan dasar untuk mengembangkan model konseptual pola pengambilan keputusan pelapak yang akan dijelaskan lebih rinci pada bagian ini. Peneliti akan fokus pada poin jenis barang, penentuan OB dan BIN, serta waktu) karena kedekatan relevansinya dengan tujuan penelitian. Dari telaah yang dilakukan, ditemukan dua model pelapak lelang AF, yaitu model oportunis dan model fair.

Model oportunis, sebuah kondisi dimana pelapak cenderung sangat berhati-hati di dalam menggelar lapak lelang. Hal ini dapat dipengaruhi oleh jenis dan kelangkaan barang juga orientasi bisnis. Pelapak oportunis cenderung "bermain-main" harga. Untuk produk yang dinilai cukup langka, maka ia akan menentukan BIN yang relatif tinggi melebihi harga pasar, bahkan terkadang ia sengaja tidak memasang BIN dan meminta penawar menghubungi melalui private message. Skema demikian sangat memungkinkan perbedaan harga untuk penawar yang berbeda. Sedangkan terkait dengan OB, hal ini dipengaruhi oleh besaran masa dan kredibilitas pelapak. Untuk pelapak besar dengan masa yang banyak, mereka lebih berani memasang OB rendah, dan sebaliknya. Pelapak cenderung coba-coba untuk meraup keuntungan sebesar-besarnya. Sebagian besar pelapak demikian adalah para penimbun barang. Mereka membeli banyak barang sekarang dan akan dijual beberapa tahun kemudian. Mereka juga hanya mereka-reka dan berharap apa yang dibeli sekarang akan mengalami kenaikan nilai kemudian.

Di dalam observasi, bahkan ditemukan pelapak lain yang memiliki pola unik. Setiap mendekati waktu penutupan lelang dan harga masih jauh dibawah pasar, selalu saja ada akun sama yang melakukan BIN atau memasang bid langsung tinggi. Ada kemungkinan ini adalah skema kerja sama atau sabotase untuk menyelamatkan pelapak dari kerugian besar. Kembali lagi bahwa sikap pelapak sangat oportunis. Namun demikian, peneliti tidak melakukan investigasi terlalu mendalam karena bukan lingkup utama penelitian. Pelapak oportunis juga lebih suka bermain-main dengan waktu. Mereka menentukan tambahan waktu dari penutupan, bisa 10 menit hingga saju jam, dan dalam rentang tersebut bisa sewatu-waktu dinyatakan tutup, jika dianggap tidak ada penawar lagi. Desakan waktu yang tidak pasti demikian akan meningkatkan emosi penawar sehingga ada kecenderungan mereka lebih berani memasang harga tawaran tinggi untuk menang. Pelapak oportunis biasanya diramaikan oleh kolektor, bukan pembeli biasa atau toko yang mengejar harga murah.

Model fair, merupakan kondisi dimana pelapak tidak terlalu memilah-milah barang dan harga secara berarti di dalam menentukan harga. Mereka hanya bersandar pada harga pasar. Jika barang tersebut langka dan harga pasar tinggi, pelapak akan mengikuti kisaran harga pasar tersebut. Jika harga pasarannya rendah, mereka juga relatif rendah. Orientasi dari pelapak memang bisnis secara fair dan pada umumnya mereka juga memiliki toko (online) untuk menjual stok secara langsung atau nonlelang dan bukan penimbun. Umumnya, aturan lelang mereka relatif sederhana dan tidak terlalu banyak bermain-main ekstensi waktu. Bagi mereka, untung dan rugi adalah bagian dari bisnis dan tidak berpikir bahwa bisnis itu selamanya untung, juga tidak selamanya rugi. 


\section{Perilaku dan Pola Pengambilan Keputusan Penawar}

Pada bagian ini peneliti akan membahas bagaimana perilaku dan pola pengambilan keputusan penawar lelang AF. ASP merupakan seorang kolektor dan berkecimpung di dunia AF sejak tahun 2015. ASP mengaku beberapa kali sempat mengikuti lelang pada beberapa lapak. "Aku sih ikut lelang kalo pas cari barang yang aku pingin. Atau bisa jadi ada barang yang dilelang masih di harga murah, biasanya iseng-iseng bid. Kalau menang pun bisa dijual lagi cari untung," cerita ASP. Hal ini menunjukkan bahwa keputusan awal ASP dalam mengikuti lelang dipengaruhi atas adanya ketertarikan. Ketertarikan dapat dimaknai dengan ketertarikan terhadap barang dan ketertarikan terhadap harga. Ketertarikan terhadap barang yang dapat dipengaruhi oleh desain, cerita, dan kesukaan dari ASP terhadap AF yang dilelang. Sedangkan ketertarikan terhadap harga dipengaruhi oleh semangat coba-coba atau oportunis untuk memperoleh barang murah dengan tujuan untuk dijual kembali demi keuntungan. Dalam hal ini, ia memilih untuk memantau pergerakan harga.

Menurut ASP, ia selalu mempertimbangkan kredibilitas pelapak yang menyelenggarakan lelang. Karena AF ini merupakan sebuah barang dan seringkali barang yang beredar di lapak lelang adalah barang bekas, maka ASP mencari pelapak yang memiliki reputasi baik. Setidaknya pelapak yang dapat dipercaya dan terbukti benar-benar menjual dan mengirim barang. Hal ini dikarenakan ASP pernah mengalami penipuan saat bertransaksi online di Facebook tanpa menggunakan rekening bersama. Selain kepercayaan bisnis, ASP juga mengamati pelapak mana yang teliti dan tidak teliti dalam memeriksa barang yang dilelang. Oleh karena transaksi ini berjalan secara online, maka sangat besar kemungkinan terjadi perbedaan ekspektasi dan kondisi riil barang.. Bagi pelapak yang sering bermasalah terkait ketelitian dalam memeriksa barang yang dilelang sebelum dilelang, maka ASP memilih untuk tidak mengikuti lelang tersebut. Karena ada risiko barang tidak dalam kondisi baik sesuai ekspektasi..

JIM adalah kolektor murni sejak tahun 2013, ia tidak membeli barang untuk dijual, kecuali dalam kondisi khusus, seperti butuh uang. Motifnya di dalam mengikuti lelang adalah untuk mendapatkan barang yang ia cari. Seperti ASP, ia juga mencari pelapak yang kredibel, namun tidak fanatik dengan satu pelapak. JIM lebih terikat pada barang yang ia cari. "Saya ngga pusing sama siapa pelapaknya, selama dia ready barang, dapat dipercaya, ya saya ikut lelang", tuturnya. Hingga saat ini, ia mengaku belum pernah ikut lelang karena iseng, tapi memang untuk berburu barang yang ia inginkan. Terkait dengan waktu lelang, JIM lebih memilih beraksi pada menit-menit terakhir penutupan. Baginya, sangat menghabiskan waktu jika harus setiap saat memantau pergerakan harga. Ia tidak tertarik pada pelapak yang bermain ekstensi waktu. Baginya akan sangat wasting time dan membuat hati tidak tenang. Dalam hal ini, JIM menjelaskan, "Detik terakhir menjelang closed sangat menegangkan, dan kadang terbawa emosi untuk melakukan BIN, daripada kehilangan barang” Terkadang, JIM langsung menghubungi pelapak untuk menanyakan BIN. Jika BIN wajar, biasanya JIM langsung saja melakukan BIN dan tarnsaksi melalui transfer ke rekening bank pelapak, tanpa jalur rekening bersama karena baginya kredibilitas pelapak sudah cukup menjadi keyakinan kejujuran pelapak di dalam bertransaksi. Sedangkan terkait dengan tampilan foto, JIM mengaku tidak terlalu peduli dengan kualitas foto. Ia menyebutkan, "Biasanya saya browsing dan cari review dulu di youtube sebelum mutusin beli AF. Jadi apapun fotonya, kalau uda tahu wujudnya ya cukuplah buat dasar beli atau enggak". Informasi AF saat ini beredar dengan sangat luas dan setiap orang mudah mengaksesnya sehingga bagi penawar lama, kualitas foto bukan hal utama.

RAF merupakan seorang pemain AF sejak tahun 2012. Pria asal Tangerang ini mengaku bahwa dirinya bermain AF hanya untuk memenuhi rasa penasarannya saja. "Gua mah beli apa yang gua suka aja. Kalo bosen ya dijual lagi kan masih bisa jadi duit," ungkap 
RAF. Apabila RAF sudah bosan dengan AF yang telah dibeli, maka dirinya akan menjual AF tersebut. "Gua sering dapet barang murah dari lelangan. Harganya juga jauh dari harga pasaran cuy. Kan dikoleksi juga happy, dijual juga untung. Tapi ya modalnya sabar aja. Ga semua lelang bisa dimenangin di harga murah," tutur RAF. Pernyataan tersebut menunjukkan bahwa motif RAF mengikuti lelang adalah untuk mencari barang murah meskipun barang tersebut tidak menjadi prioritas baginya. Peluang memperoleh barang dengan harga murah inilah yang membuat RAF lebih konservatif dan bersabar diri dalam mengikuti lelang.

"Gua kadang juga nge-BIN kalo udah ga tahan. Selama harga BIN-nya masuk akal aja sih," tutur RAF. Beberapa waktu RAF juga sempat menjadi irasional dengan melakukan BIN. Akan tetapi dirinya masih mempertimbangkan harga BIN yang ditetapkan oleh pelapak apakah masih rasional atau tidak. Dasar rasional harga BIN bagi RAF adalah perbandingan dengan harga barang yang beredar di pasaran. Apabila barang belum beredar di pasaran, maka RAF akan membandingkan harga BIN dengan harga Pre-Order. Apabila harga BIN dinilai tidak jauh lebih tinggi atau mendekati harga perbandingan, maka RAF masih mentolerir harga BIN tersebut.

Selain berdiskusi dalam kepada ketiga narasumber, peneliti juga melakukan observasi partisipatif sebagai data pendukung, dalam hal ini aktif di dalam memantau dan mengikuti lelang. Dari pengamatan, pola perilaku dari ketiga narasumber tersebut dapat dikonfirmasi. Memang ada penawar yang iseng, menang kalah bukan yang utama. Mereka hanya coba-coba untuk dapat harga termurah saja. Selain itu terdapat penawar yang memang berburu barang, mereka lebih berani memasang harga langsung tinggi atau bahkan seketika BIN. Ada pula penawar yang ingin mendaat harga murah dengan cara terus memantau dengan menaikkan bid secara perlahan. Selain itu, peneliti juga menemukan kemunculan pemawar-penawar baru pada menit-menit terkahir menjelang penutupan. Mereka memantau saja dan mulai beraksi pada jelang penutupan.

Dari proses triangulasi dan analisis temuan, dapat disimpulkan bahwa kredibilitas pelapak memang menjadi pertimbangan utama bagi penawar. Hal ini sejalan dengan penelitian Huang et. al.(2011) yang menyebutkan bahwa reputasi pelapak adalah faktor yang signifikan. Sedangkan angka OB bukan menjadi hal utama selama dinilai wajar dan tidak terlalu dekat dengan angka BIN. Terkait dengan BIN, penawar yang malas memantau proses lelang sangat mempertimbangkan nilai BIN untuk barang-barang langka. Sedangkan untuk barang pasaran, mereka lebih menyukai berburu di toko dengan harga pasti. Bagi para pejuang lelang, BIN tidak terlalu berarti dan mereka akan berjuang untuk harga terbaik dengan strategi mereka masing-masing.

Di dalam tampilan, kualitas foto bukan lagi menjadi hal penting bagi penawar AF selama pelapak memiliki nama baik. Temuan ini berbeda dengan temuan penelitian Lo et. al.(2013) yang menilai foto adalah hal yang signifikan di dalam lelang. Tentunya hal ini juga ditentukan oleh kesediaan informasi produk. Untuk produk AF, siapa saja dapat mencari review-nya di internet. Sedangkan untuk kondisi barang, biasanya pelapak cukup menuliskan pada keterangan atau mengirimkan foto detil via private message. Di luar pelapak yang kredibel, ada kemungkinan information asymetri tersebut terjadi seperti yang dibahas oleh Hogarth (1987).

\section{Aspek Perilaku dalam Praktik Lelang AF}

Bazerman (2013) memaparkan faktor-faktor yang menentukan keberhasilan atau kegagalan negosiasi. Lelang online merupakan bentuk negosiasi tidak langsung. Di dalam hal ini, pelapak dan penawar tidak bertatap muka. Mereka berinteraksi melalui wall platform Facebook. Namun demikian, peneliti tetap menemukan kesamaan antara proses negosiasi 
langsung maupun tidak langsung (online). Berikut pembahasan faktor-faktor tersebut pada lelang AF.

Mythical Fixed Pie, di dalam lelang AF, barang-barang langka bagaikan kue yang valumenya tetap. Tidak mudah ditemukan bahkan tidak ada lagi di pasaran. Hal ini bisa terjadi karena memang jumlah produksi barang tersebut tidak banyak dan sudah lama tidak ada reiisue. Bagi pelapak khususnya kolektor, tidak memungkinkan untuk mencari kue lain. JIM mengatakan, "Ada satu AF lininya SHF Kinnikuman, pas pre order 2 tahun lalu harganya sekitar Rp.900.000,- dan sekarang barang itu cuma dijual di Jepang dengan harga Rp.1.700.000,-. Untuk barang-barang pasaran, tentunya mitos ini dengan mudah dipatahkan.

Framing, proses framing sering dilakukan oleh pelapak. Mereka mudah membuat isu "barang langka", "masih murah", atau "memasuki 5 menit terakhir". Desakan psikologis ini akan memicu emosi pelapak. Para kolektor cenderung tidak lagui berpikir logis. Mereka hanya berpikir untuk memiliki barang tersebut berapapun harganya. Jatuh cinta terhadap AF akan memicu Escalation of Non Rational Commitment. Sudah terlanjutr bid dan mendekati kemenangan, tak jarang penawar meneruskan perjuangannya demi mengejar kesenangannya. Mereka tidak lagi berpikir rasional dan pada akhir perjuangan seringkali muncul penyesalan. Seperti diungkap JIM, "Kadang sih nyesel juga dapet barang kemahalan. Tapi kalo barang itu rare hati juga bisa pelan-pelan tenang". Pernyataan demikian merupakan rasionalisasi atau yang disebut dengan self serving, upaya untuk menghibur diri dengan mencari hal baik apa yang didapat dari sebuah "kerugian".

\section{Model Konseptual Perilaku Penawar Lelang AF}

Berbagai analisis dan pembahasan sebelumnya akan dijadikan dasar untuk mengembangkan model konseptual perilaku dan pola pengambilan keputusan penawar lelang AF. Dari telaah yang dilakukan, ditemukan 5 pola perilaku dan pengambilan keputusan penawar lelang, yaitu Iseng, Konservatif, Agresor, Sniper, Biner. Iseng, adalah penawar yang motifnya coba-coba saja. Menang atau kalah bukan masalah utama. Mereka berpikir, siapa tahu dapat harga murah. terkadang, mereka menyukai lelang yang sepi dan memulai OB. Jika beruntung, mereka akan mendapatkan barang dengan harga OB yang jauh di bawah harga pasar. Di dalam perjalanan lelang, biasanya si iseng akan lenyap dengan sendirinya ketika harga sudah mulai mendekati harga pasar dan cenderung melebihi.

Konservatif, adalah penawar yang menaikan bid secara perlahan, misalnya persepuluh ribu rupiah. Mereka sangat berhati-hati menjaga posisi harga. Bagaimanapun posisi kenaikan yang dipasang oleh pesaing, tipe konservatif akan tetap memasang bid perlahan. Sebaliknya, tipe agresor, adalah mereka yang memasang angka bid dengan jeda atau jarak yang cukup besar. Sebagai contoh, pada saat ini posisi bin adalah Rp.500.000,- dengan syarat bid adalah kelipatan Rp.20.000,-. Dengan mudah, kaum agresor memasang angka pada posisi Rp.700.000,-. Demikian pula selanjutnya. Tipe ini juga disebut sebagai bomber.

Sniper, mereka adalah penawar yang hanya beraksi di menit terakhir. Selama ini hanya memantau pergerakan harga. Motif mereka sebagian besar adalah koleksi, karena biasanya mendekati menit penutupan, harga bid sudah makin tinggi. Mereka tidak terlalu sensitif pada harga dan motifnya untuk memperoleh barang, bukan kehilangan uang. Namun demikian mereka sedikit oportunis. Sedangkan mereka yang motifnya murni mendapat barang disebut sebagai biner.

Terdapat dua jenis biner. Pertama, mereka yang masih berpikir rasional dengan membandingkan angka BIN dengan harga pasar. Jika masih mendekati atau bahkan di bawah, mereka akan segera BIN. Jika tidak, mereka mungkin akan menjadi tipe penawar lain. Kedua, mereka yang sudah tidak berpikir rasional dan seketika itu BIN. Hal ini dapat terjadi karena memang kelangkaan barang dan harsrat yang terlalu besar dari penawar untuk memiliki 
barang tersebut. Dalam dunia AF, BIN tidak tergantung pada gender seperti penelitian Yeh (2012) yang menemukan bahwa kaum feminism lebih memilih BIN daripada berjuang, namun lebih pada kadar kemelekatan penawar dengan produk. Ketika penawar semakin melekat pada "nyawa" AF, maka peluang BIN akan selalu lebih besar dan sebaliknya. Di dalam perjalanan putaran lelang, perilaku penawar bisa saja berubah dan hal ini sangat dipengaruhi oleh kondisi psikologi penawar. Hal ini yang memang belum diungkap secara mendalam di dalam penelitian ini mengingat tujuan dan lingkup penelitian yang terfokus pada permodelan konseptual pelapak dan penawar lelang AF.

\section{KESIMPULAN}

Lelang AF merupakan fenomena unik yang tidak banyak diketahui orang. Terdapat perputaran uang dengan nilai yang besar dengan pasar yang sangat spesifik (ninche). Sifat spesifik dan unik inilah yang menjadikan lelang AF memiliki poin-poin perbedaan dengan lelang barang lain dan teori umum. Penelitian ini mengungkap data empiris dari perspektif pelapak lelang dan penawar lelang sehingga mendapatkan gambaran yang holistik tentang lika-liku lelang AF. Dari telaah yang dilakukan, ditemukan dua model pelapak lelang AF, yaitu model oportunis dan model fair. Dari telaah yang dilakukan, ditemukan 5 pola perilaku dan pengambilan keputusan penawar lelang, yaitu Iseng, Konservatif, Agresor, Sniper, Biner.

\section{DAFTAR PUSTAKA}

Bazerman, Max H. 2013. Judgement in Managerial Decision Making. John Wiley \& SOns, Inc.

Burrell, G. dan Morgan G., 1979. Sociological Paradigms and Organizational Analysis. Ashgate Publishing.

Chiou, Jyh Shen; Lei Yu Wu; dan Yi Ping Sun. 2009. Buyer Satisfaction and Loyalty Intention in Online Auctions. Journal of Service Management vol. 20, no. 5, 2009, pp. 521-543.

Gulden, T. 2015. A System Analysis of Transmedia Storytelling Toys in Relation to Desire and Pleasure. 6th International Conference on Applied Human Factors and Ergonomics (AHFE 2015) and the Affiliated Conferences, AHFE 2015: Procedia Manufacturing 3 ( 2015 ) hal. 2071-2078.

Hogarth, Robin M. 1987. Judgement and Choice. $2^{\text {nd }}$ Edition. Willey Interscience Publication. Huang, Yi Chun; Yen Chun Jim Wu; Yu Chin Wang; dan Nolan Christopher Boulanger. 2011. Decision Making in Online Auctions. Management Decision vol. 49, no.5, 2011, pp 784-800.

Mickhail, G., 2000. The Kabuki of Accounting Philosophy, Document de Recherche $\mathrm{N}^{0}-2000$ 7, Laboratoir Orleanais de Gestion, Intitut D'Administration des Entreprises.

Neuman, W. L. 2011. Social Research Methods: Qualitative and Quantitative Approaches. $7^{\text {th }}$ edition. New Jersey: Pearson Education Inc.

Yeh, J. C., J. L. Hsiao, dan Wei Ning Yang. 2012. A Study of Purchasing Behavior in Taiwan's Online Auction Websites. Internet Research vol. 22, no.1, 2012, pp. 98-115. 
LAMPIRAN 1

\begin{tabular}{|c|c|c|c|c|c|}
\hline No. & Pelapak & Jumlah Follower & $\begin{array}{l}\text { Rata-rata } \\
\text { Jumlah } \\
\text { Barang } \\
\text { yang } \\
\text { Dilelang }\end{array}$ & $\begin{array}{l}\text { Rata-rata } \\
\text { Omzet per } \\
\text { Lelang }\end{array}$ & $\begin{array}{c}\text { Intensitas } \\
\text { Lelang }\end{array}$ \\
\hline 1 & $\begin{array}{l}\text { Addict } \\
\text { Hobby Store } \\
\text { (AHS) }\end{array}$ & $\begin{array}{l}\text { Facebook friend: } \\
1.911 \text { akun } \\
\text { Fanpage like: } \\
1.352 \text { like }\end{array}$ & 8-15 barang & $\begin{array}{c}\text { Rp 4.000.000,- } \\
\text { s/d } \\
\operatorname{Rp} 6.000 .000,-\end{array}$ & $\begin{array}{l}1-2 \text { kali } \\
\text { sebulan }\end{array}$ \\
\hline 2 & $\begin{array}{l}\text { Andri Andri } \\
\text { Andri } \\
(\text { AAA) }\end{array}$ & $\begin{array}{l}\text { Facebook friend: } \\
4.944 \text { akun }\end{array}$ & $\begin{array}{c}15-18 \\
\text { barang }\end{array}$ & $\begin{array}{c}\text { Rp } 8.000 .000,- \\
\text { s/d } \\
\text { Rp 18.000.000,- }\end{array}$ & Setiap hari \\
\hline 3 & $\begin{array}{l}\text { Efendi } \quad \text { Lo } \\
\text { (EFL) }\end{array}$ & $\begin{array}{l}\text { Facebook friend: } \\
4.903 \text { akun }\end{array}$ & $\begin{array}{c}14-24 \\
\text { barang }\end{array}$ & $\begin{array}{c}\text { Rp } 16.000 .000,- \\
\text { s/d } \\
\text { Rp 22.000.000,- }\end{array}$ & $\begin{array}{c}1-3 \text { kali } \\
\text { seminggu }\end{array}$ \\
\hline 4 & $\begin{array}{l}\text { Hanseen } \\
\text { Wang } \\
\text { (HAN) }\end{array}$ & $\begin{array}{l}\text { Facebook friend: } \\
5.000 \text { akun }\end{array}$ & $\begin{array}{c}15-22 \\
\text { barang }\end{array}$ & $\begin{array}{c}\text { Rp } 15.000 .000,- \\
\text { s/d } \\
\text { Rp 22.000.000,- }\end{array}$ & $\begin{array}{c}\text { 3-4 kali } \\
\text { seminggu }\end{array}$ \\
\hline 5 & $\begin{array}{ll}\text { Hendy } & \text { Dev } \\
\text { (HEN) } & \end{array}$ & $\begin{array}{l}\text { Facebook friend: } \\
4.091 \text { akun }\end{array}$ & $\begin{array}{c}16-24 \\
\text { barang }\end{array}$ & $\begin{array}{c}\text { Rp } 10.000 .000,- \\
\text { s/d } \\
\text { Rp } 20.000 .000,-\end{array}$ & $\begin{array}{c}\text { 3-4 kali } \\
\text { seminggu }\end{array}$ \\
\hline 6 & $\begin{array}{l}\text { Lutfi Indra } \\
\text { Kurniawan } \\
\text { (LUT) }\end{array}$ & $\begin{array}{l}\text { Facebook friend: } \\
4.968 \text { akun }\end{array}$ & $\begin{array}{c}20-30 \\
\text { barang }\end{array}$ & $\begin{array}{c}\text { Rp } 6.000 .000,- \\
\text { s/d } \\
\text { Rp 10.000.000,- }\end{array}$ & Setiap hari \\
\hline 7 & $\begin{array}{l}\text { Rubenz } \\
\text { Haryana } \\
\text { (RUB) }\end{array}$ & $\begin{array}{l}\text { Facebook friend: } \\
4.999 \text { akun }\end{array}$ & $\begin{array}{c}20-25 \\
\text { barang }\end{array}$ & $\begin{array}{c}\text { Rp } 8.000 .000,- \\
\text { s/d } \\
\text { Rp 20.000.000,- }\end{array}$ & $\begin{array}{c}5-7 \text { kali } \\
\text { seminggu }\end{array}$ \\
\hline 8 & $\begin{array}{l}\text { Victor } \\
\text { Wikondo } \\
\text { Raharjo } \\
\text { (VWR) }\end{array}$ & $\begin{array}{l}\text { Facebook friend: } \\
4.328 \text { akun } \\
\text { Private group } \\
\text { member:3.168 } \\
\text { akun }\end{array}$ & $\begin{array}{c}10-20 \\
\text { barang }\end{array}$ & $\begin{array}{c}\text { Rp 6.000.000,- } \\
\text { s/d } \\
\text { Rp 14.000.000,- }\end{array}$ & $\begin{array}{c}5-7 \text { kali } \\
\text { seminggu }\end{array}$ \\
\hline 9 & $\begin{array}{l}\text { Willy } \\
\text { Hosana } \\
\text { (HSN) }\end{array}$ & $\begin{array}{l}\text { Facebook } \\
\text { follower: } \\
5.537 \text { akun } \\
\text { Private group } \\
\text { member: } \\
1.633 \text { akun }\end{array}$ & $\begin{array}{c}10-15 \\
\text { barang }\end{array}$ & $\begin{array}{c}\operatorname{Rp} 8.000 .000,- \\
\text { s/d } \\
\text { Rp } 14.000 .000,-\end{array}$ & $\begin{array}{c}1-3 \text { kali } \\
\text { seminggu }\end{array}$ \\
\hline 10 & Samz Gun & $\begin{array}{l}\text { Facebook } \\
\text { follower } 399 \text { akun }\end{array}$ & $\begin{array}{c}10-30 \\
\text { barang }\end{array}$ & $\begin{array}{c}\text { RP 5.000.000,- } \\
\text { s/d } \\
\text { Rp 12.000.000,- }\end{array}$ & $\begin{array}{c}1-2 \text { kali } \\
\text { seminggu }\end{array}$ \\
\hline
\end{tabular}

